\title{
IMPLEMENTASI STRATEGI PENGAWASAN KOMISI PENYIARAN INDONESIA (KPI) TERHADAP PROGRAM TELEVISI DALAM MEWUJUDKAN SIARAN RAMAH ANAK
}

\author{
Maulidya Agustina, Dedy Hermawan, Ita Prihantika \\ Jurusan IImu Administrasi Publik, Fakultas IImu Sosial dan IImu Politik Universitas Lampung, \\ E-mail: itaprihantika@fisip.unila.ac.id
}

\begin{abstract}
Children's programs currently served are not in accordance with the classification of programs during children's broadcast hours and children's content that contains violence and contains more foreign animation than local children's shows. Therefore, Komisi Penyiaran Indonesia (Indonesian Broadcasting Commission), which was formed as an independent institution, has the authority to compile and supervise various broadcasting regulations that connect broadcasting institutions requiring a strategy in monitoring television programs in realizing child-friendly broadcasts. This study aims to describe and analyze the implementation of the strategy of Komisi Penyiaran Indonesia in monitoring television programs to achieve childfriendly broadcasts. This research was conducted with a descriptive qualitative approach. Data collection was carried out by interview, documentation and observation. The results of this study indicate that the implementation of the strategy of Komisi Penyiaran Indonsia is quite good but there are still shortcomings in the budget and target recipients, namely broadcasting institutions that are still committing violations. The implementation strategy is formulated into a program, in the form of Bimbingan Teknis Penyiaran Anak, Anugerah Penyiaran Ramah Anak and Pengaturan Isi Siaran Anak.
\end{abstract}

Keywords: Child Friendly Broadcasts, Programs, Budget, Procedures

\begin{abstract}
Abstrak
Program tayangan anak saat ini disajikan tidak sesuai dengan klasifikasi program pada jam tayang anak serta konten tayangan anak yang memuat kekerasan dan lebih banyak bermuatan tayangan animasi asing dari pada tayangan lokal anak. Oleh sebab itu, Komisi Penyiaran Indonesia yang dibentuk sebagai lembaga independen memiliki kewenangan (otoritas) menyusun dan mengawasi berbagai peraturan penyiaran yang menghubungkan antara lembaga penyiaran memerlukan strategi dalam pengawasan terhadap program televise dalam mewujudkan siaran ramah anak. Penelitian ini bertujuan untuk mendeskripsikan dan menganalisis implementasi dari strategi Komisi Penyiaran Indonesia dalam pengawasan terhadap program televisi dalam untuk mewujudkan siaran ramah anak. Penelitian ini dilakukan dengan pendekatan kualitatif deskriptif. Pengumpulan data dilakukan dengan wawancara, dokumentasi dan observasi. Hasil penelitian ini menunjukkan bahwa pada pengimplementasian strategi yang dimiliki Komisi Penyiaran Indonesia cukup baik namun masih ada kekurangan dalam anggaran dan penerima sasaran yaitu lembaga penyiaran yang masih melakukan pelanggaran. Strategi implementasi dirumuskan ke dalam sebuah program, berupa kegiatan Bimbingan Teknis Penyiaran Anak, Anugerah Penyiaran Ramah Anak dan Pengaturan Isi Siaran Anak.
\end{abstract}

Kata kunci: Siaran Ramah Anak, Program, Anggaran, Prosedur 


\section{PENDAHULUAN}

Kemajuan teknologi merupakan hal yang penting di era globalisasi. Seperti pendapat Abbas (2003) era globalisasi yang telah berkembang membuat informasi menjadi sesuatu yang vital, kemampuan dan kecepatan seseorang mengakses dan menganalisis informasi menjadi langkah awal untuk me-menangkan persaingan hidup yang makin kompetitif.

Media televisi saat ini menjadi salah satu andalan bagi masyarakat untuk mencari dan melihat informasi. Media televisi sebagai sarana tayangan realitas sosial menjadi penting bagi manusia untuk memantau diri dalam kehidupan sosialnya. Temuan Nielsen Media Research tahun 2005 menunjukkan televisi memiliki daya penetrasi jauh lebih besar daripada media informasi lainnya. Penetrasi televisi mencapai $91,7 \%$, sedang surat kabar, majalah, tabloid, sinema dan radio, masing-masing hanya mencapai $25,7 \%, 22,9 \%, 16,1 \%, 1,2 \%$ dan $42,1 \%$. Relasi anak dengan televisi telah menjadi persoalan yang problematik. Disatu sisi, televisi telah menjadi sarana transferensi ide, nilai, norma dan transformasi mental kearah penyadaran, pencerahan dan kemajuan kehidupan. Namun, disisi lain, televisi dapat menularkan pengaruh buruk yang mendegradasikan format kemanusiaan dan kemampuan berpikir anak (Venus dalam Fardiah 2005).

UU Penyiaran sudah mengatur tentang isi siaran yang sehat dan layak di tonton oleh masyarakat khususnya oleh anak-anak. Pasal 36 ayat (3) UU Penyiaran menyebutkan bahwa isi siaran wajib memberikan perlindungan dan pemberdayaan kepada anak-anak dan remaja. Hal ini membuktikan bahwa UU Penyiaran mengamanatkan kepada lembaga penyiaran untuk melakukan berbagai kajian dan juga sensor terhadap isi siaran yang tidak layak ditonton oleh anak-anak akan tetapi, sampai dengan saat ini permasalahan tayangan yang tidak layak ditonton oleh anak-anak masih banyak terjadi.

Saat ini televisi yang ada di Indonesia belum mempunyai program yang memisahkan antara tontonan yang layak di tonton oleh orang dewasa atau tayangan yang layak di tonton oleh anak-anak. Hal ini akan menimbulkan dampak negatif terhadap pergaulannya. Seperti dampak yang ditimbulkan setelah tayang program Sinetron Cinta Anak Muda pada tahun 2019, anak remaja SMP menunjukkan gaya pacaran layaknya orang dewasa. Gaya pacaran seperti memeluk dan berciuman sudah tidak menjadi hal yang tabu dan menjadi kebiasaan yang normal.

Stasiun televisi juga dilarang menyajikan program dan promo program yang mengandung adegan dianggap diluar perikemanusiaan atau sadistis atau yang dapat dipersepsikan sebagai mengagung-agungkan kekerasan atau menjustifikasi kekerasan sebagai hal yang wajar dalam kehidupan sehari-hari. Program atau promo program yang mengandung muatan kekerasan secara dominan, atau mengandung adegan kekerasan eksplisit dan vulgar. Program-program tersebut hanya dapat disiarkan pada jam tayang dimana anak-anak pada umumnya diperkirakan sudah tidak menonton televisi, yaitu pukul 22.00-03.00 sesuai dengan waktu stasiun penyiaran yang menayangkan.

Komisi Penyiaran Indonesia (KPI) dibentuk sebagai lembaga independen yang mempertegas prinsip bahwa pengelolaan sistem penyiaran yang merupakan ranah publik harus dikelola oleh sebuah badan yang bebas dari intervensi modal maupun kepentingan kekuasaan. 
Untuk menjaga semangat berdirinya komisi, maka dinyatakanlah visi dan misi KPI. Visi KPI disusun dalam dimensi jangka panjang sedangkan pernyataan misi KPI diharapkan mampu mencakup maksud yang ingin dicapai, sarana pencapaiannya serta nilai atau prinsip dasar yang menjadi dasar keyakinan KPI dalam pencapaian maksud tertentu. Misi akan memandu penetapan posisi dan pilihan peran KPI dalam konstalasi para pihak yang terlibat dalam bidang penyiaran.

Dalam rangka menjalankan fungsinya KPI memiliki kewenangan (otoritas) menyusun dan mengawasi berbagai peraturan penyiaran yang menghubungkan antara lembaga penyiaran, pemerintah masyarakat. Pengawasan Menurut Hasibuan (2009) dalam Fatimah (2014), pengawasan dapat diartikan sebagai perbuatan untuk melihat dan memonitor terhadap orang agar ia berbuat sesuai dengan kehendak yang telah ditentukan sebelumnya.

Pengaturan pengawasan yang dilakukan oleh KPI ini mencakup semua daur proses kegiatan penyiaran, mulai dari tahap pendirian, operasionalisasi, pertanggung jawaban, dan evaluasi. Dalam melakukan semua ini, KPI berkoordinasi dengan pemerintah, dan lembaga negara lainnya, karena spectrum pengaturannya yang saling berkaitan. KPI juga berhubungan dengan masyarakat dalam menampung dan menindaklanjuti segenap bentuk apresiasi masyarakat terhadap lembaga penyiaran maupun terhadap dunia penyiaran pada umumnya.

KPI saat ini belum dapat dikatakan menjalankan tugas secara maksimal sehingga memunculkan berbagai permasalahan dalam menjalankan fungsi, tugas, dan kewenangannya untuk melindungi anak-anak dari siaran televisi yang tidak baik. Terdapat masih banyak lembaga penyiaran televisi yang belum melaksanakan rekomendasi KPI terkait dengan tayangan televisi yang ramah anak. Selain itu, sanksi yang diberikan oleh KPI juga masih dirasakan lemah, sehingga lembaga penyiaran masih banyak yang berani melanggar ketentuan yang terdapat dalam peraturan perundang-undangan dan P3SPS.

\section{METODE}

Tipe penelitian yang digunakan dalam penelitian ini adalah deskriptif, yaitu menggambarkan sebuah fenomena atau kejadian dengan apa yang sebenarnya terjadi dan apa adanya. Sedangkan pendekatan yang digunakan adalah pendekatan kualitatif, maka peneliti diharapkan dapat melihat fenomena-fenomena yang ada, yakni tentang bagaimana implementasi strategi pengawasan Komisi Penyiaran Indonesia (KPI) terhadap program televisi dalam konteks upaya perlindungan anak dan remaja di Indonesiaserta apa saja kendala-kendala yang dapat menghambat implementasi strategi pengawasan Komisi Penyiaran Indonesia (KPI) terhadap program televisi dalam upaya perlindungan anak dan remaja di Indonesia.

Objek penelitian ini adalah Kantor Pusat Komisi Penyiaran Indonesia (KPI) di Jalan Ir. H. Juanda No. 36, RT.7/RW.2, Kb. Klp., Kecamatan Gambir, Kota Jakarta Pusat, Daerah Khusus Ibukota Jakarta. Data primer diperoleh melalui teknik wawancara dan observasi, sedangkan data sekunder diperoleh melalui studi dokumen dan pustaka. Untuk menjaga keabsahan data, peneliti menggunakan derajat kepercayaan (credibility), (2) keteralihan (transferability), kebergantungan (dependability), (4) 
kepastian (konfirmability) (Moleong, 2010).

\section{PEMBAHASAN}

Permasalahan tayangan program anak dalam televisi dijadikan rekomendasi dalam berupaya untuk mewujudkan siaran ramah anak. Salusu (2006) mengatakan strategi umumnya membahas tujuan dan sasaran. Organizational goals adalah keinginan yang hendak dicapai di waktu yang akan datang, yang digambarkan secara umum dan relative tidak mengenal batas sedangkan organization objectives adalah pernyataan yang sudah mengarah pada kegiatan untuk mencapai goals.

Sebagai sebuah organisasi, KPI bertanggung jawab dalam mewujudkan penyiaran yang sehat. Sesuai dengan konsep tersebut, KPI menuangkan rencana dalam pencapaian tujuan tersebut dalam rencana strategi dan rekomendasi Rakornas yang menyatakan visi- misi tersebut dengan Implementasi Strategi Pengawasan Terhadap Program Televisi melalui 3 program, yaitu Bimbingan Teknis Penyiaran Anak, Anugerah Penyiaran Ramah Anak dan Pengaturan Isi Siaran Anak yang sudah dilaksanakan namun belum sesuai dengan target dan sasarannya.

Setelah strategi utama dan sasaran jangka panjang ditetapkan, maka proses selanjutnya yang penting adalah mengimplementasikan strategi dalam bentuk program (Untoro dan Hakim, 2007). Implementasi strategi menurut Wheelen dan Hunger (2003) berkaitan dengan pelaksanaan implementasi strategi pengawasan terhadap program televisi dalam mewujudkan siaran ramah anak melalui pengembangan program, anggaran dan prosedur.

\section{Program}

Menurut Wheelen dan Hunger (2003) program adalah pernyataan aktivitas-aktivitas atau langkah-langkah yang diperlukan untuk menyelesaikan perencanaan sekali pakai. Program melibatkan restrukturisasi perusahaan, perubahan budaya internal perusahaan, atau awal dari suatu usaha penelitian baru. Program yang telah dilaksanakan oleh KPI menjadi rekomendasi dalam Rapat Koordinasi Nasional pada tahun 2018 dengan mendorong terwujudnya penyiaran ramah anak. Adapun program-program yang telah dilaksanakan oleh KPI adalah sebagaiberikut.

a) Bimbingan Teknis Penyiaran Anak KPI melaksanakan pembinaan rutin kepada lembaga penyiaran melalui bimbingan teknis penyiaran. Pembinaan rutin menjadi fokus bagi KPI dalam melakukan pengawasan pada siaran anak yang berkaitan dengan masalah hak privasi, perlindungan anak, muatan seksual dan jurnalistik serta isu horror mistik dan supranatural serta memberikan pemahaman secara detail kepada lembaga penyiaran televisi. Pembinaan yang dilakukan secara rutin oleh KPI adalah Sekolah P3SPS. Program ini juga dikolaborasikan bersama KemenPPPA untuk membekali kalangan media untuk menghasilkan program-program siaran ramah anak.

Dalam kenyataanya masih terdapat pelanggaran yang dilakukan program televisi. Salah satunya Program Sinetron Anak Langit SCTV, pada tanggal 26 Agustus 2019 pukul 17.12 menampilkan adegan perkelahian antar beberapa orang pria dengan frekuensi dan durasi perkelahian dinilai cukup 
masif sehingga bertentangan dengan SPS Pasal 15 ayat (1) dan 37 ayat 4 huruf (a). perlindungan anak dari program yang menampilkan perilaku tidak pantas agar anak tidak menganggap perilaku yang tidak pantas tersebut sebagai hal yang lumrah dalam kehidupan sehari-hari.

Penerapan Bimbingan Teknis pada lembaga penyiaran televisi dalam mewujudkan siaran ramah anak dikatakan sudah cukup baik namun belum diterima secara produktif oleh lembaga penyiaran televisi sehingga menyebabkan tidak implementatif secara baik dalam praktiknya dan menemukan indikasi berbagai pelanggara yang dilakukan oleh program televisi yang sangat bertentangan dalam P3SPS serta dapat merusak kesehatan psikis anakanak.

b) Anugerah Penyiaran Ramah Anak Anugerah Penyiaran Ramah Anak 2019 diberikan untuk memicu peningkatan kesadaran lembaga penyiaran agar menyuguhkan program siaran anak yang sehat dan berkualitas. Melalui anugerah ini, KPI ingin lembaga penyiaran televisi memiliki persaingan yang sehat dalam menciptakan banyak program khusus anak yang sehat, mendidik, informatif, ramah terhadap anak, berkualitas sekaligus menghibur.

Terdapat 7 kategori yang diperlombakan dalam program ini antara lain kategori animasi Indonesia, kategori animasi asing, kategori variety show, kategori feature atau dokumenter, kategori sinetron anak/remaja, kategori program anak dan radio dan kategori favorit pilihan anak. Catatan selama penilaian terhadap program-program siaran yang dilombakan dalam program anak ini antara lain kemunculan iklan-iklan yang tidak sesuai dengan kepentingan anak, bahkan bisa jadi bertolak belakang, kualitas program anak yang baik namun belum dikemas professional sebagaimana selera anak.

KPI sudah cukup baik dalam peningkatan kesadaran lembaga penyiaran untuk selalu menyuguhkan siaran anak yang sehat dan berkualitas dengan menyelenggarakan Anugerah Penyiaran Ramah Anak sebagai apresiasi. Sebagai bahan evaluasi dan pembelajaran terhadap KPI terdapat catatan-catatan penilaian bagi industri penyiaran untuk terus melakukan perbaikan.

c) Pengaturan Isi Siaran Anak

KPI memiliki kewenangan menyusun dan mengawasi berbagai peraturan penyiaran yang menghubungkan lembaga penyiaran, pemerintah dan masyarakat dengan pengaturan yang berkaitan dengan kegiatan penyiaran dengan mengeluarkan P3SPS.

Jadwal penayangan program anak sesuai dengan klasifikasi program khususnya di sore hari dimulai pukul 15.00-18.00 di hari Senin-Minggu/libur nasional. Berdasarkan hasil observasi pada 3 program televisi yaitu ANTV, MNC TV dan TRANS TV, program didominasi oleh acara yang sifatnya umum seperti serial program, reality show, film, entertainment; news dan informasi, olahraga dan lain-lain dengan segmentasi orang dewasa. 
Anak-anak tidak diperlakukan sebagai penonton-penonton khusus, dimana tidak ada waktu khusus acara diprogramkan untuk anak-anak.

Program pengaturan isi siaran anak televisi masih belum maksimal dikarenakan masih minimnya jumlah program anak pada program televisi serta anak-anak tidak diperlakukan sebagai penonton-penonton khusus, dimana tidak ada waktu khusus acara diprogramkan untuk anak-anak.

\section{Anggaran}

Wheelen dan Hunger (2003) menyatakan budget atau anggaran merupakan suatu rencana yang disusun secara sistematis dalam bentuk angka dan dinyatakan dalam unit moneter yang meliputi seluruh kegiatan perusahaan untuk periode di masa yang akan datang. Setelah semua program yang dibutuhkan disusun, maka diperlukan pembuatan anggaran untuk memperkirakan biaya yang harus dikeluarkan.

Anggaran KPI Pusat sepenuhnya berasal dari Anggaran Belanja Pendapatan Negara (APBN). Hal ini sesuai dengan pasal 15 UU Nomor 32 Tahun 2002 tentang Penyiaran bahwa sumber pembiayaan Lembaga Penyiaran Publik berasal dari iuran penyiaran; APBN dan APBD dan Belanja Daerah, sumbangan masyarakat, siaran iklan, dan usaha lain yang terkait dengan penyelenggaraan penyiaran. Setiap akhir tahun anggaran, Lembaga Penyiaran Publik wajib membuat laporan keuangan yang diaudit oleh akuntan publik dan hasilnya diumumkan melalui media massa.

Anggaran yang diterima oleh Komisi Penyiaran Indonesia pada tahun 2016 jumlah total sebesar Rp.
48.182.400.000, dan meningkat pada tahun 2017 dengan jumlah total Rp. 51.060.282.000, pada tahun 2018 mengalami peningkatan dengan jumlah Rp. 51.381.082.000, dan tahun anggaran 2019 berjumlah Rp. 54.134.130.000. Pada tahun 2020, alokasi anggaran KPI berjumlah sebesar Rp. $\quad 55.065 .754 .000$ untuk melaksanakan strategi pengawasan terhadap program televisi namun dapat dikatakan belum cukup dalam memenuhi kebutuhan program karena dana yang diberikan tidak sesuai dengan dana yang diajukan oleh KPI sehingga saat mengevaluasi kinerja, KPI hanya berfokus pada survey publik, tidak didasarkan pada pertimbangan yang lain.

\section{Prosedur}

KPI memiliki kewenangan untuk memberikan sanksi terhadap pelanggaran peraturan dan pedoman perilaku penyiaran serta standar program siaran. Dalam perspektif perlindung anak, KPI tidak menerapkan sanksi kekhususan baik secara objektif maupun subjektif, namun didasarkan kepada mekanis penjatuhan sanksi berdasarkan P3SPS.

Adapun sanksi administratif yang diterima lembaga penyiaran dalam penjatuhan hukuman antara lain teguran, penghentian sementara acara yang bermasalah setelah melalui tahap tertentu, penghentian sementara acara yang bermasalah setelah melalui tahap tertentu, denda administrative, pembekuan kegiatan siaran untuk waktu tertentu, tidak diberi perpanjangan izin penyelenggaraan penyiaran, serta pencabutan izin penyelenggaraan penyiaran.

Berdasarkan teori Wheelen dan Hunger (2003) yang melihat program, anggaran dan prosedur sebagai tolak ukur strategi layak atau tidak untuk 
diimplementasikan,

peneliti memberikan kesimpulan bahwa implementasi strategi pengawasan KPI terhadap program televisi dalam mewujudkan siaran ramah anak belum dikatakan cukup maksimal. Dari tolak ukur program, peneliti melihat KPI sudah cukup baik dalam menyelenggarakan program seperti Bimbingan Teknis Penyiaran Anak, Anugerah Penyiaran Ramah Anak serta Pengaturan Isi Siaran Anak namun masih lemahnya pengawasan sehingga memungkinkan masih terdapat pelanggaran yang dilakukan program televisi. Tolak ukur anggaran dikatakan belum cukup maksimal untuk memenuhi kebutuhan KPI dalam memfasilitasi lembaga penyiaran. Namun, penerapan tindakan melalui mekanisme penjatuhan sanksi pada lembaga penyiaran sudah dilakukan secara maksimal berdasarkan ketentuan P3SPS.

Menurut Wahyudi (2006) terdapat 3 karakteristik tayangan anak meliputi acara yang diperuntukkan bagi anakanak, selain harus disajikan pada saat anak belum tidur, isi pesannya, baik audio maupun visualnya harus sesuai dengan selera anak-anak, program TV harus mampu memberikan dasar pemikiran yang jelas, sesuai dengan norma dan etika yang berlaku dan mengapa cerita serta adegan itu dibuat dan disajikan, serta program TV yang cocok untuk anak-anak adalah perkembangan ilmu pengetahuan dan teknologi, sejarah perjuangan bangsa, nilai-nilai budaya bangsa. Namun pada kenyataannya, tayangan anak pada program televisi semakin menurun dan tergerus serta digantikan dengan program-program yang tidak sesuai dengan jam tayang yang seharusnya dan program-program yang tidak mendidik untuk perkembangan psikologis anakanak.
Menurut Fardiah (2006), beberapa alasan yang turut menjadi kekhawatiran bahwa anak-anak setiap kali dijadikan sasaran ekspansi pasar melalui media televisi, karena merupakan sasaran proses konsumsi jangka panjang, mengingat usia hidupnya yang lama; Anak-anak masih dalam proses pengembangan kepribadian, sehingga sangat mudah dipengaruhi oleh berbagai hal, karena anak-anak lebih mengandalkan emosi dibandingkan rasionalitas dalam pengambilan keputusan; Anak-anak semakin terjerat menjadi objek barang-barang industri; tayangan televisi yang melibatkan anak hanya menawarkan sebuah khayalan; tayangan televisi juga dianggap menebarkan unsur-unsur kekerasan dan pornografi bagi anak-anak.

Pengaturan regulasi dan program anak-anak harus melewati dengan ketentuan seleksi. Regulasi yang ada seharusnya menjadi pedoman bagi KPI dan lembaga penyiaran televise untuk mencari format yang tepat dalam memadukan antara aspek komersial dan aspek siaran ramah anak. Dalam Fardiah (2006) menyampaikan banyak upaya yang bias dilakukan baik secara kuantitas, program tayangan anak harus ditingkatkan diantara tayangantayangan umum dan orang dewasa yang menjadi tugas para industri penyiaran televisi, pemerintah atau masyarakat juga harus ikut terlibat dalam proses ini sesuai dengan porsinya masing-masing.

\section{PENUTUP}

Berdasarkan hasil penelitian dan pembahasan maka penulis menyarankan lembaga penyiaran seharusnya lebih banyak menayangkan tayangan lokal anak dalam program siaran televisi yang juga memuat pesan formatif dan edukatif kepada anak-anak; Komisi Penyiaran Indonesia membuat regulasi atau dasar hukum yang jelas terhadap 
siaran ramah anak untuk mewujdukan tayangan anak yang ideal; serta perlu diadakan sosialisasi secara masif yang mendalam kepada masyarakat awam khususnya orang tua agar terlibat aktif dalam pengawasan terhadap anak-anak dan melaporkan setiap tindakan kepada KPI jika terdapat tayangan progam yang tidak sesuai dengan ramah anak.

\section{DAFTAR PUSTAKA}

Abbas, B. (2003). Komunikasi Peran dan Permasalahannya. Jakarta: Yayasan Kampus Tercinta IISIP.

Hunger, J. D. \&Wheelen, T. L. (2003).

Manajemen

Strategis.

Yogyakarta: Andi.

Moleong, L.J. (2010). Metoda Penelitian Kualitatif. Bandung: PT Remaja Rosdakarya.

Fardiah, D. (2006). Tinjauan Kritis Tentang Program Tayangan Anak di Televisi. Jurnal Komunikasi
Mediator, $\quad 7(2), \quad$ 299-310. doi:10.29313/1291

Fatimah, S. 2014. Kajian Konsep Pengawasan dan Disiplin Kerja. Jurnal Ilmu Sosial, 12 (1), April, 2014.

Salusu, J. (2006). Pengambilan Keputusan Strategik untuk Organisasi Publik dan Organisasi Nonprofit. Jakarta: PT Gramedia Widiasarana Indonesia

Untoro, W., \& Hakim, A. (2007). Startegic Management In The Public Sector Organization: Publicness Implication On The Process And Dimension. Jurnal Bisnis dan Manajemen, 7(1).

Wahyudi, J. (1994). Dasar-Dasar Manajemen Penyiaran. Jakarta: Gramedia Pustaka Utama 